\title{
The medical movement and Dr. Ismael Cosío Villegas. At half a century
}

\author{
José Luis Sandoval-Gutiérrez
}

Secretaría de Salud, Instituto Nacional de Enfermedades Respiratorias, Department of Pulmonology, Ciudad de México, Mexico

\begin{abstract}
In 1964, medical residents and interns of the Mexican Republic decided to carry out a work stoppage that stretched over for several months. Several prominent doctors decided to join the causes that motivated the movement, among which Dr. Ismael Cosio Villegas, who at that moment was the director general of the Huipulco hospital for tuberculosis patients; his participation and dedication are historical, and his determination caused for his resignation to be demanded. His trajectory remains practically unknown by the medical community.
\end{abstract}

KEY WORDS: History of medicine. Medical movement. Ismael Cosío Villegas. Instituto Nacional de Enfermedades Respiratorias. National exam for medical residency.

By the end of 1964, at the 20 de Noviembre Hospital of the Institute of Security and Social Services of the State Workers (ISSSTE - Instituto de Seguridad y Servicios Sociales de los Trabajadores del Estado), currently National Medical Center 20 de Noviembre, a demonstration of intern and resident physicians took place due to the discontinuation of annual bonus payment, together with repeated inattentions towards the medical personnel, which caused for them to go on strike, ${ }^{1}$ which consisted of minimal on-call duties and only care of patients with emergency medical or surgical situations.

In no time, hospitals from different health systems joined in, such as Hospital General de México, Hospital Juárez, Hospital Rubén Leñero and some hospitals from entities that now are considered National Institutes of Health; subsequently, medical centers from Guadalajara and Monterrey joined in. By the end, different hospitals from other states joined this peaceful uprising that, because of being led by health personnel, was named the White Movement. ${ }^{2}$

Its main demonstration was the "walk of silence" (Fig. 1), where the contingent of doctors, supported by nursing personnel, went through Mexico City's center carrying placards and signs exposing demands, requests and slogans; numerous participants of the contingent walked with their lips sealed with wound dressing materials. Formations were made in the city main square. Most spectators showed solidarity with the movement, but there were also some who insulted the group, and there was also presence of trouble makers. Those were times with little tolerance for this type of expressions; Mexico's incumbent president showed no sympathy for the representative commission.

The negative to dialogue caused for the movement to prolong for several months. The National Medical Alliance was formed, which organized the meetings and debates about the situation and that unfortunately disappeared after the movement. To this moment there have not been voices showing the will of civil reorganization of a national medical association that syndicates practitioners of the country, regardless of their specialty or clinical training, as it occurs in other countries. $^{3}$

Few media gave coverage to the situation that was going on, and when they did, in no few occasions it was to discredit the movement.
Date of reception: 14-07-2015

Date of acceptance: 15-07-2015

DOI://dx.doi.org/10.24875/GMM.M18000136
Gac Med Mex. 2018;154:206-209

Contents available at PubMed www.gacetamedicademexico.com 
Doctors and nurses were forced out from hospital centers, even with groups of riot police at 20 de Noviembre Hospital, where the movement had started (Fig. 2).

Half a century has elapsed since that expression of the medical community, during which several of its leaders were fired, including doctor Ismael Cosío Villegas, a pulmonologist and chest surgeon, at that moment general director of the Huipulco Hospital for Tuberculosis Patients, currently National Institute of Respiratory Diseases "Ismael Cosío Villegas" (IMER - Instituto Nacional de Enfermedades Respiratorias Ismael Cosío Villegas) (Fig. 3). Doctor Cosío Villegas refusal to stop supporting those doctors who were part of the movement caused for his resignation to be demanded, which he exactly complied with on January $15,1965 .{ }^{4}$ In his letter of resignation to the technical council he expressed the following:

I feel sorry for leaving this hospital, which I have served with loyalty, affection and perseverance for 28 years, but I don't want my colleagues and students to lose the faith and the trust placed in my modest personality, which I have tried to forge based on disinterest, civil responsibility and the highest spirit of comradeship.

In his letter to the Ministry of Health he wrote:

I am not resentful with anybody, and I am especially calm and in agreement with my behavior. Tell the minister that this document comes as no surprise to me because I was expecting it, tell him also that leaving Huipulco, under these circumstances, is for me a badge of honor.

Dr. Cosío Villegas retired to the academic circles and to his private practice, was appointed professor emeritus by the National Autonomous University of Mexico (UNAM - Universidad Nacional Autónoma de México) and Doctor Honoris Causa by the Autonomous University of Puebla, but he never went back home, today's National Institute of Respiratory Diseases, which since 2006 carries his name (Fig. 4).

In 1977, he was given a tribute for his 50-year trajectory at the National Institute of Cardiology (Figure 5), with the presence of Doctor Ignacio Chávez and representatives of the National Academy of Medicine, which was chaired by doctor Cosío Villegas in 1961. On that occasion, doctor Chávez expressed:

He arrives to old age with the pride of his clean, hard-working and productive life, leaving behind his work as a legacy for medical generations that follow. [...]

The man we came to honor is above everything a natural-born teacher. His students follow and admire him, and this proves that they find gifts of wisdom in him. But there is something else, they follow him, and that proves they find gifts of generosity in him. [...]

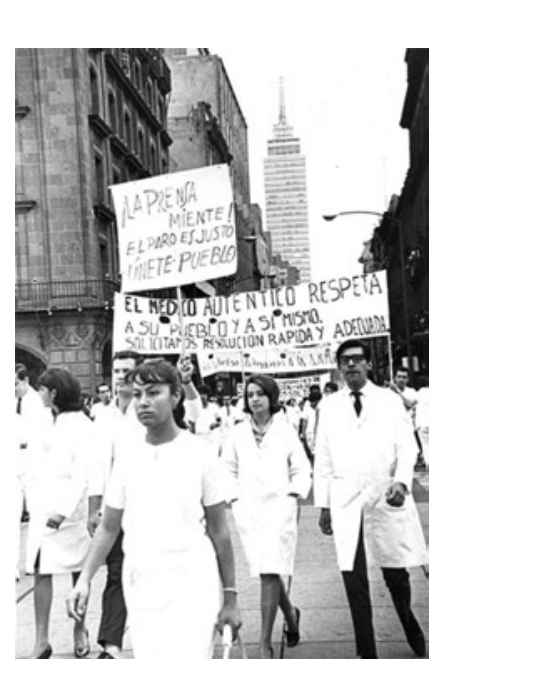

Figure 1. White Movement demonstration in Mexico City, 1964. Image obtained from http://www.kehagoaqui.com.

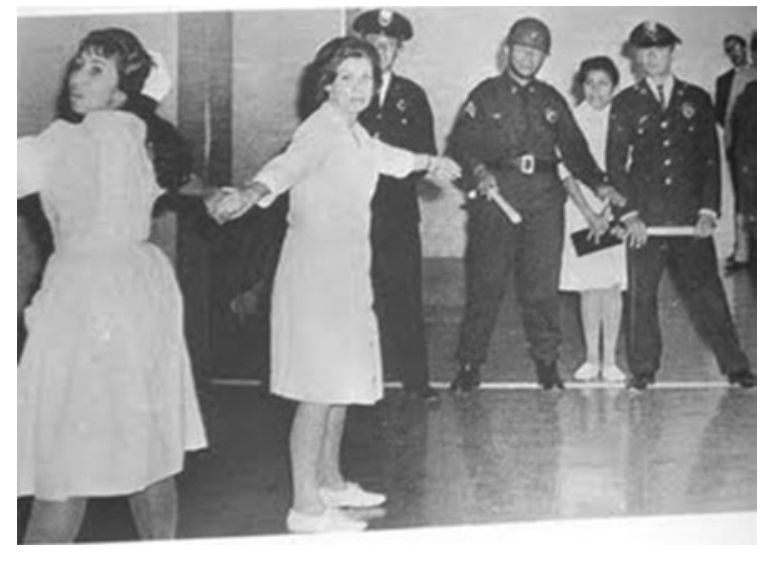

Figure 2. Nursing personnel support to the medical group to avoid evacuation at the 20 de Noviembre Hospital (ISSSTE). Image obtained from https://enlacecursoshistoria.files.wordpress.com/2009/11/el-movimiento-medico-004.jpg.

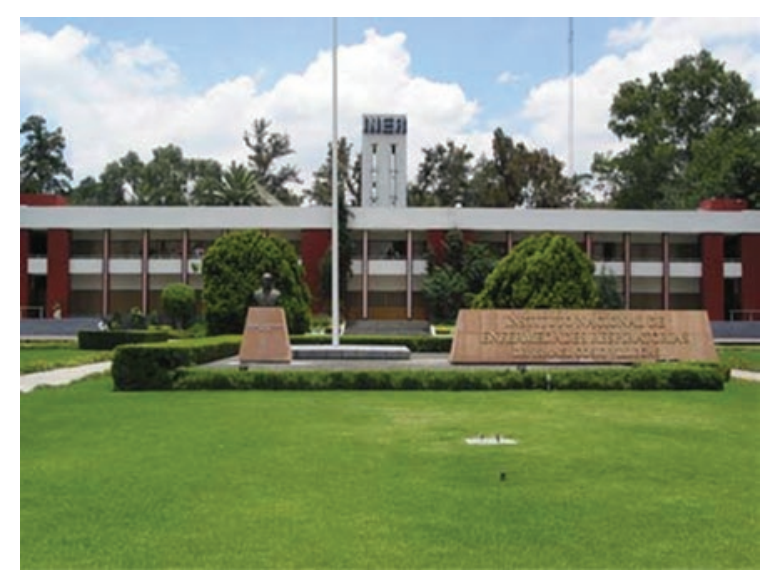

Figure 3. Image of the National Institute of Respiratory Diseases "Ismael Cosío Villegas"; at the main entrance and square, a bust of the professor is observed. Image obtained from http://www.iner.salud. gob.mx/media/70152/english_vhome.jpg. 


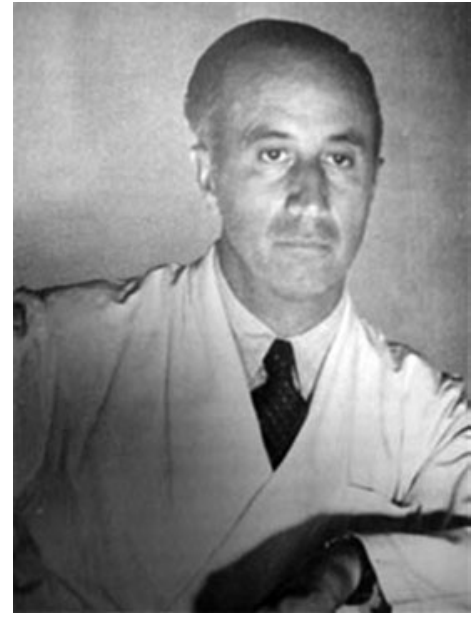

Figure 4. Doctor Ismael Cosío Villegas. Image obtained from http:// www.facmed.unam.mx/sms/seam2k1/2008/oct_04_ponencia.html.

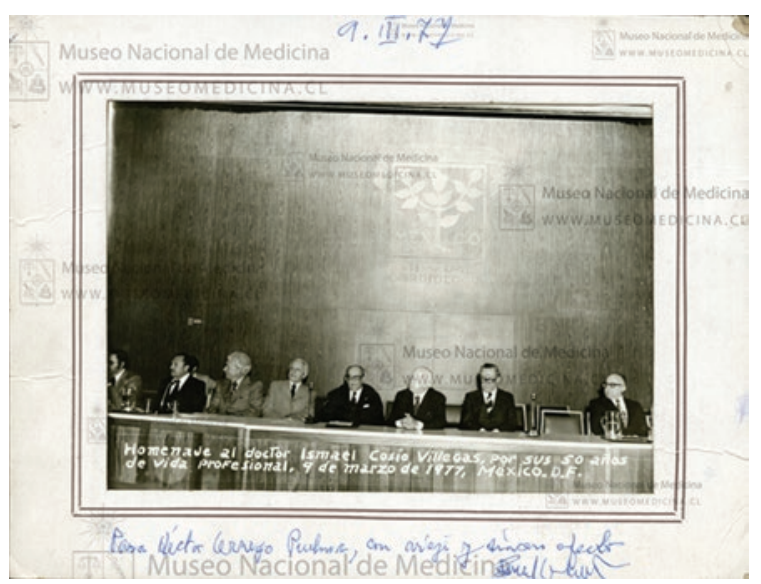

Figure 5. Doctor Ismael Cosío Villegas, at third place from right to left; doctor Ignacio Chávez at fourth. Image obtained from http://bibliotecadigital.uchile.cl/client/search/asset/57936.

With blindness, the country thus sentenced one of its highest values in teaching to retirement, (but) life has not crooked his soul as to others. [...]

Time has proven the struggle led by him half a century ago morally and ideologically right.

During the ceremony for doctor Cosío Villegas name inclusion to the INER, Doctor Raúl Cicero mentioned:

\begin{abstract}
In his final years, Cosío Villegas was given weak tributes by different groups. The Professor died on August 2, 1985; but the reality is that his human value has not been fully acknowledged, which was consistent in thought and action, and neither has his work as a teacher of Mexican pulmonology. At the General Hospital of Mexico, from where Cosío Villegas came to found this honorable Institute, we learned to respect and care for him. Alejandro Celis, Carlos Pacheco, Octavio Rivero, Raúl Cicero, José Kuthy, Hermilo Esquivel Medina, among others -our teachers-, thus showed us to respect Cosío Villegas.
\end{abstract}

On one occasion, 54 years ago, professor Cosío stated in a session of the Academy:
Social man has the necessity of justice, which is accomplished only with the disappearance of public immorality, (and) in this justice resides the revolutionary plan of our times: better distribution of wealth, parity in rights and obligations, respect for human values, these are issues of social physiology.

Much of the wisdom and thoughts of the Professor was shared by him with great personalities of his time: Diego Rivera, Frida Khalo, Siqueiros, José Gaos, Gabriela Mistral, Pablo Neruda, Guadalupe Amor, Narciso Bassols; as well as with other doctors: Salvador Zubirán, Federico Gómez, Isaac Costero, Rosenblueth, Gustavo Baz, Ignacio Chávez, just to mention some, who recognized doctor Cosío Villegas skills and leadership, which indicates his high intellectual quality.

There is much to analyze of the White Movement: it was the precedent for today's medical residencies enjoying adequate registry and recognition, for a national exam for medical residency aspirants (EXARM - Examen Nacional de Aspirantes a Residencias Médicas) ${ }^{5}$ being carried out, for selected physicians having the right to a scholarship, to training ruled by an academic plan with institutional and college recognition, and for specialists being certified by their respective council and obtaining a professional license.

Doctor Norberto Treviño, one of the most prominent leaders of the movement, expressed some time:

The medical movement constituted the most widely spread and vigorous attempt to reach medical unity, (but) the result was division, silence of the medical community. Today, at 40 years of that movement, that effort was not in vain; doctors' characteristics as workers, their economic and social problems, and their safety as individuals and professionals are recognized and considered to be legitimate.

Things that today are taken for granted, 50 years ago weren't a reality. Currently, it is incredible for the medical community and even recent graduates from medical school to know the 1968 and 1971 student movements to the perfection, and even the railroad worker's movement, but to ignore the White Movement,- which was previous to the above mentioned ones.

As 1964 movement heir phenomena, two movements can be mentioned, which were organized in 2014:

- I am 17, started by doctors from all over the country to support 16 practitioners from Guadalajara charged with murder for the decease of a patient with critical pulmonary disease; the father of the adolescent, a lawyer, tried to blame the group that looked after his son. 
It appears that the demands of the medical community have not been satisfied and the spirit of the White Movement shows up every now and then.

- The other movement was organized by nurses from all over the country who fought for their labor rights and staged a sit-in in front of the Ministry of Health headquarters in order to stop category change at their workplaces.

There is a need for a historical review and exchange of ideas about the White Movement, which empowered medical specialties, but repressed its heads and punished its leaders, including the pillar of Mexican pulmonology, doctor Ismael Cosío Villegas.

In 1989, Doctor Carlos Pacheco mentioned:

Cosío Villegas knew men and catalogued them adequately. He was hard on those deserving it, but he never was merciless with the less fortunate or hassled the weak; he was a proud man. A man of solid political ideas. He was able to give up his brilliant career to commit himself into ostracism, as a silent protest in defense of his convictions and as a slap in the face of those who so unfairly took actions against him.

Mexican journalist, publisher, cultural promoter, indigenist and intellectual Fernando Benítez expressed the following:

He trained generations of doctors and, when the time came, he fought for his colleagues' freedom and dignity. A pioneer of pulmonology, Ismael is one of the most extraordinary men I have ever met; he has maintained a strange fidelity to his ideas in a land of opportunists. A fighter for justice, he devoted his life to defend his deepest convictions.

On February 4 of the present year, a general session was celebrated at the INER Auditorium, chaired by Doctor Jaime Villalba Caloca, pioneer of lung transplantation and former general director of the Institute, where Doctor Cosío Villegas participation in the medical movement was commemorated.

Professor Cosío Villegas was consistent with his feelings, thoughts and acts. Although he died 30 years ago, it is necessary for his works to be diffused in medical schools and faculties, in order to make justice to one of our most remarkable scientific personalities.

As Mexican philosopher Antonio Caso said "we have to equate our thoughts with life". Professor Cosío followed this rectitude until death.

\section{References}

1. Sandoval-Gutiérrez JL. A 35 años del movimiento médico en México. Med Int Med. 2000;16(3):157-159.

2. Pozas-Horcasitas R. La democracia en blanco: el movimiento médico en México, 1964-1965. México: Siglo XXI; 1993.

3. American Medical Association. [Sitio web]. [Consultado 2015 Jul 9]. Disponible en: http://www.ama-assn.org/ama.

4. Wikipedia, la enciclopedia libre [Sitio web]. Ismael Cosío Villegas. Disponible en: https://es.wikipedia.org/wiki//smael_Cos\%C3\%ADo_Villegas.

5. Comisión Interinstitucional para la Formación de Recursos Humanos para la Salud. [Sitio web]. [Consultado 2015 Jul 8]. Disponible en: http:// www.cifrhs.salud.gob.mx. 